\title{
Kalmár, György. 2017. Formations of Masculinity in Post- Communist Hungarian Cinema: Labyrinthian Men. Cham, Switzerland: Springer Nature (for Palgrave Macmillan Imprint). 164 pp.
}

\author{
Reviewed by Clara Orban, ${ }^{*}$ DePaul University
}

Hungarian films created in East-Central Europe after the fall of communism share quite a few similarities with films from other former Soviet-bloc countries. György Kalmár, a researcher of visual arts at the University of Debrecen, argues that post-1989 Hungarian Cinema portrays masculinities in ways similar to those of other East-Central European cinemas due to their shared history and cultural reality. First liberated from communist control and then, in the early 2000s, admitted into the European Union, these countries experienced elation, anxiety, and disappointment at different stages and in varying degrees during this period. Inevitably, these realities are reflected in the films made in these countries. In particular, in his informative cinematic analysis, Kalmár provides a reading of masculinity in films that are constructed according to what he calls a "labyrinth principle," meaning a recurring stress on the ways in which the lives of post-1989 Hungarian men revolve in vicious prison-like circles and frames. Interspersed throughout his study are autobiographical self-references alluding to how Kalmár himself had lived this change of social and political order. As the author notes, the films under discussion in his work were all created after those examined in John Cunningham's Hungarian Cinema: From Coffee House to Multiplex (2004), to this day one of the most important overviews of Hungarian cinema. In his lifetime, Kalmár experienced both state socialism and capitalism, as did almost all the directors discussed in his Formations of Masculinity in PostCommunist Hungarian Cinema. This allows the author to provide personal anecdotes to help his readers understand the paradox of new Hungarian films that remember, interpret, and come to terms with their "afterwardsness" (ix), meaning their state of being trapped between two worlds.

Chapter one provides a definition of the labyrinth principle and delineates the shared traits of the films that are discussed in the book's various chapters. Here Kalmár also discusses important pre-1989 films that had already been shown to include labyrinthian principles and thus feature damaged masculine identities. Béla Tarr's 1982 Panelkapcsolat ['The Prefab People'], for example, begins with a musical band playing in a courtyard surrounding a housing complex. As the camera keeps rotating slowly, "the shot expresses confinement, circularity, and the feeling of

*CORBAN@depaul.edu

$($ (c) $)$ EY

ULIS D-Senk
New articles in this journal are licensed under a Creative Commons Attribution 4.0 International License.

This journal is published by the University Library System of the University of Pittsburgh as part of its D-Scribe Digital Publishing Program and is cosponsored by the University of Pittsburgh Press 
Orban, Clara. "Kalmár, György. 2017. Formations of Masculinity in Post-Communist Hungarian Cinema: Labyrinthian Men. Cham, Switzerland: Springer Nature (for Palgrave Macmillan Imprint). 164 pp." Hungarian Cultural Studies. e-Journal of the American Hungarian Educators Association, Volume 13 (2020) DOI:

watching a circus attraction" (1), thus presenting the people living in the prefab housing-complex and looking out their windows as though they were living in cages. The idea of trapped people likewise informs Kalmár's reading of Miklós Jancsó's Szegénylegények ['The Roundup'] (1966), with its "maze-like spaces and its hopeless, vulnerable protagonists" (11). In this film, though, the filmmaker punctuates the claustrophobic images of a fort's interior by shots of the expansive vistas of the Hungarian puszta, wild wasteland. The labyrinth principle is essential to understanding Kalmár's analysis, for one of the basic theoretical assumptions of this book is that "formations of masculinity in film cannot be separated from the (cinematic) spaces in which they appear: the (often labyrinth-like, often limiting or suffocating) spaces of these films define the kinds of characters that can appear in them" (xviii). In fact "the labyrinth is much more than a simple motif: it looks more like a persuasive principle organising several characteristic features of these films" (8). As the analysis of these earlier films shows, the labyrinth principle that continues to inform the later Hungarian Art House cinema structured even canonical Hungarian films (9).

The book's subsequent chapters provide analyses of films from the period following the regime change. The first of these chapters offers an analysis of Ferenc Török's Moszkva tér ['Moscow Square'] (2001), a film featuring historical ruptures and ironic masculinities. Kalmár notes that, breaking away from the traditional historical and social commitment of Hungarian cinema, in Moszkva tér history serves as but a backdrop about which the characters hardly care. This way, then, the film is "organised by a distinctively contemporary cultural phenomenon: the human subject's falling out of history, and the general disintegration of grand historical narratives" (26). This realization leads the author to provide personal reminiscences as someone who lived under state dictatorship, which is a necessary perspective, he notes, for understanding this film's departure from the traditional social commitment of Hungarian cinema. The author notes that Hungarian cinema tends to foreground historical events, while in this film, events appear only as a mediatized backdrop to the characters' lives. Concerning masculinity, in this film the characters are presented as outsiders to the grand narrative of history, as well as marginalized in or by their own society (36).

The second chapter addresses György Pálfi's experimental film titled Hukkle ['Hiccup'] (2002). Like many of the films studied in Kalmár's Formations of Masculinity, this one also features men on the margins of history. Here, too, Kalmár's point remains that these films express an anxiety about the new political situation in which Hungarians found themselves after the regime change. In the new reality patriarchy is challenged and men fail when confronted with the uncertainty of this new situation. Hukkle "performs a reevaluation of the human being and men in particular, a dislocation of the human subject (as the subject of the gaze or subject of the story), it turns against the ideological and cinematic constructions of humanism, and connects the spectator with personal and collective memories in ways that bypass history, ideology, and the symbolic" (51). Hukkle avoids any dialogue and Kalmár notes that in the absence of an overarching narrative, the spectator may uncover the traumatic historical events related here, in this case the Tiszazug murders, meaning the interwar affair of altogether some forty cases of rural women poisoning their menfolk. This series of murders that largely remained unresolved and undocumented seems to attest, according to Kalmár (who bases his claim on Anikó Imre's Identity Games: Globalization and the Transformation of Media Cultures in the New Europe; Cambridge: MIT Press, 2009), to a symptom of an "impending, full-blown crisis of masculinity" (61) in which the men of the landscape are practically and symbolically erased from it. 
Orban, Clara. "Kalmár, György. 2017. Formations of Masculinity in Post-Communist Hungarian Cinema: Labyrinthian Men. Cham, Switzerland: Springer Nature (for Palgrave Macmillan Imprint). 164 pp." Hungarian Cultural Studies. e-Journal of the American Hungarian Educators Association, Volume 13 (2020) DOI:

The third chapter analyzes Nimród Antal's 2003 film Kontroll ['Ticket Inspection']. This film lends itself to a convincing analysis of the labyrinth principle and masculinity in Hungarian film because its setting very explicitly provides tortuous routes, barred exits, blind tunnels and other dead ends representing the maze from which the Budapest-subway ticket-inspectors can never escape. For Kalmár, Kontroll represents the time soon after the regime change, when old and new ways of life coexisted in a contradictory and confusing intersection. In the visual labyrinth of the capital's subway, where the characters continually look for a way out, "Kontroll takes the spectator to a (culturally constructed) land struggling with issues of (post-)coloniality, exploitation and inferiority complexes, at a time when coming to terms with the past and the evaluation of possible futures are key aspects of the historical situation" (68). The tension inherent in this film derives from a culturally dominant system or order, and from the presence and actions of people seeking an identity in that underground space (71). Given that Kontroll also includes very few female characters in an almost entirely male cast, this film strengthens Kalmár's argument of linking masculinity and the labyrinth, thus highlighting the disconnection between "male subjectivity and power(-knowledge)" (80).

The fourth chapter offers an analysis of Szabolcs Hajdu's Fehér tenyér ['White Palms'] 2006). This semi-autobiographical film of a male gymnast from Debrecen is largely made up of the gymnast's flashbacks of his Hungarian past from the perspective of his new life in the West. This film follows the general outline of the sports-film genre but deviates from it by focusing on "sensitively composed images of bodies [that] express symbolic meanings far beyond the usual horizon of most international generic examples" (95). This sports film is analyzed according to parameters particular to this subgenre, even though Fehér tenyér portrays masculinity not necessarily as part of or leading to victory narratives. In this analysis of the film, the gym is a thinly veiled reference to totalitarian regimes that subjugate the body and crush the spirit. This chapter allows Kalmár to examine sports in Hungarian identity-politics through a series of important moments that brought Hungarian sports and politics together, such as the Golden Team of National football (this team was unbeaten from 1950 to 1954, and filmic representations of its exploits were previously studied by Cunningham). Similar to the characters in Jancsó's Szegénylegények, the white-palmed boys in the socialist-state gym are caught in a dystopian arena of cruelty and imprisonment mingled with a national-patriotic rhetoric of pride (112).

In the fifth chapter, Kalmár's analysis of Kornél Mudruczó's Szelíd teremtés: A Frankenstein-terv ['Tender Son: The Frankenstein Project'] (2010) explores how this film portrays fathers and their demons. This reinterpretation of the Frankenstein story can be understood "as a cinematic study of the implications of post-totalitarian fatherhood or as the representation of the experience of people brought up in societies torn by historical trauma" (124). While the main character is not, technically speaking, an orphan, he is abandoned by his parents and raised in an institution. This leads Kalmár to briefly discuss the orphanage, a common place-motif in Hungarian film history, which in Szelíd teremtés provides a labyrinthine space for exploring the aggressor rather than his victims through a series of shots linked by images of the abyss (for example via a dizzying staircase) (131).

The sixth and last chapter discusses Csak a szél ['Just the Wind'] (2012), a film made by Benedek Fliegauf and addressing the issue of Roma people in Hungary. This film is partly based on some unsolved cases of attacks against Hungarian Roma people at the end of the first decade of the new millennium. With its central focus on race relations between Roma and white Hungarians, this film pushes adult male characters to the margins by limiting the amount of time 
Orban, Clara. "Kalmár, György. 2017. Formations of Masculinity in Post-Communist Hungarian Cinema: Labyrinthian Men. Cham, Switzerland: Springer Nature (for Palgrave Macmillan Imprint). 164 pp.” Hungarian Cultural Studies. e-Journal of the American Hungarian Educators Association, Volume 13 (2020) DOI:

and the capacity in which they appear on screen. Adult masculinity in this film consists of problematic figures, with both Roma and non-Roma adult males essentially excluded from the visual universe. In this final case-study, Kalmár sees the labyrinth as a space or existence out of which the characters no longer wish to escape but rather retreat back into the confusing maze of their marginal existence.

Augmented with film stills to highlight important points, this study of New Hungarian Cinema provides an interesting outline of important films from the new millennium and will be of interest to those interested in film as well as in recent Hungarian social and cultural studies. 